\title{
A role for RNA stability in the induction of HTLV-1 expression in chronically-infected CD4+ T cells
}

\author{
Hsin-Ching Lin ${ }^{1,2,3}$, Peter Simon², Arnold B Rabson 1,2,3,4,5* \\ From 16th International Conference on Human Retroviruses: HTLV and Related Viruses \\ Montreal, Canada. 26-30 June 2013
}

The pathogenesis of HTLV-1-associated diseases involves complex interactions between HTLV-1 and the infected host, and is dependent on viral replication and gene expression. Previous studies from our laboratory have shown that $\mathrm{T}$ cell receptor- and phorbol ester (PMA)-mediated stimulation of chronically infected CD4 T-cells increases the expression of integrated HTLV-1 proviruses. Detailed analysis of HTLV-1 RNA and protein species following PMA treatment of the FS and SP HTLV-1-infected T cells demonstrated rapid induction of tax/rex mRNA peaking prior to other HTLV-1 RNA species. This rapid increase in tax/rex mRNA was associated with markedly enhanced tax/rex mRNA stability. (from $3.5 \mathrm{hr}$ to $>24 \mathrm{hr}$ in treated cells), while the stability of unspliced or singly spliced HTLV1 RNAs did not increase. PMA treatment also increased RNA transcription. These data contrast with a delayed increase in HTLV-1 RNA transcription following treatment the HDAC inhibitor, SAHA. To further identify the elements and mechanisms responsible for enhanced tax/rex RNA stability, we adapted a luciferase reporter assay in which tax/rex cDNA sequences were linked to the 3 ' end of luciferase gene. Increased luciferase activity was observed with this reporter plasmid upon PMA treatment, as compared with a reporter plasmid containing tax antisense sequences. Our data support a model whereby $\mathrm{T}$ cell activation leads to increased HTLV-1 gene expression through increased tax/rex mRNA stability, which in turn results in induction of Tax protein expression, and further activation of HTLV-1 gene expression, and associated changes in cellular gene

* Correspondence: rabsonab@umdnj.edu

${ }^{1}$ The Child Health Institute of New Jersey, USA

Full list of author information is available at the end of the article expression, contributing to increased $\mathrm{T}$ cell survival and proliferation and disease.

\section{Authors' details}

${ }^{1}$ The Child Health Institute of New Jersey, USA. ${ }^{2}$ The Cancer Institute of New Jersey, USA. ${ }^{3}$ Department of Pharmacology, UMDNJ-RWJMS, New Brunswick, NJ, USA. ${ }^{4}$ Department of Pathology and Laboratory Medicine, UMDNJRWJMS, New Brunswick, NJ, USA. ${ }^{5}$ Department of Pediatrics, UMDNJ-RWJMS, New Brunswick, NJ, USA.

Published: 7 January 2014

\section{doi:10.1186/1742-4690-11-S1-P114}

Cite this article as: Lin et al: A role for RNA stability in the induction of HTLV-1 expression in chronically-infected CD4+ T cells. Retrovirology 2014 11(Suppl 1):P114.
Submit your next manuscript to BioMed Central and take full advantage of:

- Convenient online submission

- Thorough peer review

- No space constraints or color figure charges

- Immediate publication on acceptance

- Inclusion in PubMed, CAS, Scopus and Google Scholar

- Research which is freely available for redistribution
() Biomed Central 